The Review of Politics 84 (2022), 214-237.

(C) The Author(s), 2022. Published by Cambridge University Press on behalf of University of Notre Dame. This is an Open Access article, distributed under the terms of the Creative Commons Attribution licence (https://creativecommons.org/ licenses/by/4.0/), which permits unrestricted re-use, distribution, and reproduction in any medium, provided the original work is properly cited.

doi:10.1017/S0034670522000018

\title{
Political Compromise and Dirty Hands
}

\section{Edward Hall}

\begin{abstract}
In this article, I offer a novel account of why compromising in politics is likely to involve the kind of politically admirable but morally wrongful behavior at stake in the dirty hands thesis. On the view I defend, politicians do not dirty their hands just because they compromise on matters of principle. Rather, when forging a political compromise, negotiators can either comply with the requirements of ethical compromise-making or abide by the special obligations they have to their representees, but will struggle to satisfy both demands. As a result, subsequent to such compromises, residual moral claims about how the compromise was negotiated will almost inevitably emerge and compromise-makers will not be able to explain their conduct in a way that can cancel these grievances. It is in this sense that forging political compromises can be "dirty" even if choosing to compromise is the politically responsible thing to do.
\end{abstract}

Many scholars of political ethics who address the problem of dirty hands include "compromising" in their list of acts that admirable politicians will sometimes engage in but that nevertheless implicate them in wrongdoing. ${ }^{1}$ Unfortunately, they rarely explain why forging political compromises has

Edward Hall is a senior lecturer in political theory in the Department of Politics and International Relations at the University of Sheffield, Elmfield Building, Sheffield S10 2TU, England, United Kingdom (edward.hall@sheffield.ac.uk).

I thank for their feedback audiences at the Geneva Colloquium in Political Theory, the Hungarian Academy of Sciences, and the White Rose Political Theory Seminar, and Richard Bellamy, Alasdair Cochrane, George Coiley, Derek Edyvane, Carl Fox, Andrew Hindmoor, Christina Nick, Alasia Nuti, Paul Sagar, Matt Sleat, Fabian Wendt, Ruth Abbey, and three anonymous reviewers for the Review of Politics.

${ }^{1}$ One must thus distinguish between dirty compromises, which ought to be made despite the moral wrongdoing they involve, and so-called rotten compromises which some argue should never be forged. This article addresses the former. For discussion of the latter see Avishai Margalit, On Compromise and Rotten Compromises (Princeton: Princeton University Press, 2010). 
this worrying moral consequence. I offer a novel account of why political compromise-making is highly likely to do so in adversarial democratic regimes. My argument is that subsequent to the forging of a political compromise a politician's representees or their co-compromisers (and sometimes both) are likely to have residual moral claims about how the compromise was negotiated. Political compromise-makers will often not be able to explain or justify their conduct in a way that cancels these grievances. So even if forging a particular political compromise is the politically responsible thing to do, and can thus be vindicated on balance, the act of compromising is highly likely to generate moral wrongdoing of the sort involved in standard accounts of the problem of dirty hands. This is because representatives who must negotiate political compromises face two conflicting moral demands which they cannot fully satisfy. On the one hand, they must accord with the requirements of ethical compromise-making while, on the other, they must act as faithful and committed advocates for their representees. ${ }^{2}$

I start by setting out the problem of dirty hands. I then examine the nature of political compromises, outlining the cursory ways much of the extant literature frames the relationship between dirty hands and political compromise before addressing Chiara Lepora and Robert Goodin's sophisticated account of why, even if it can be justified overall, compromising on matters of principle generates serious moral costs. Following this, I argue that despite the merits of their account, Lepora and Goodin cannot explain why politicians who opt to compromise on matters of principle have engaged in the kind of moral wrongdoing at stake in the dirty hands debate. Having made this point, I develop my main argument that compromising in politics is likely to require one to dirty one's hands by showing that a conflict obtains between the ethical requirements of good compromise-making and the obligations that apply to professional politicians as representatives who are tasked with robustly advocating for their representees. In the penultimate section, I respond to a number of counterarguments to my view.

\footnotetext{
${ }^{2}$ This second point is often downplayed in the literature on compromise in political theory, which overwhelmingly addresses the question of how, if at all, compromising on matters of principle can be justified-with reciprocity, mutual respect, and public justification being the most commonly considered candidate values. For influential discussions see Richard Bellamy, Liberalism and Pluralism: Toward a Politics of Compromise (London: Routledge, 1999); Christian Rostboll, "Democratic Respect and Compromise," Critical Review of International Social and Political Philosophy 20, no. 5 (2017): 619-35; Fabian Wendt, Compromise, Peace, and Public Justification: Political Morality beyond Justice (London: Palgrave, 2016). Cf. Simon May, "Principled Compromise and the Abortion Controversy," Philosophy \& Public Affairs 33, no. 4 (2005): 317-48. Given that, in one way or another, nearly all political disputes involve conflicts of principle this is clearly an important question. However, this should not obscure (and does not determine) other important ethical questions about compromising in politics, such as the one I pursue in this article.
} 


\section{The Problem of Dirty Hands}

The proposal that admirable agents may sometimes have to engage in action that should be morally condemned is at the beating heart of the so-called "problem" of dirty hands. ${ }^{3}$ If they do, adherents of the dirty hands thesis suggest they are guilty of moral wrongdoing and that a "lingering sense of wrongness" should be preserved in our judgment of their behavior. ${ }^{4}$ Some philosophers balk at the dirty hands thesis for this reason, alleging that it offends against basic standards of rationality via its implication that one does right and wrong simultaneously. ${ }^{5}$ But defenders of the thesis insist that it is entirely possible that agents, reasoning in good faith, can be moved "by moral considerations to commit moral violations." ${ }^{6}$ The political interest of the dirty hands thesis arises from the fact that we have reason to believe that such situations arise regularly in politics. Indeed, it is commonly claimed that politicians may have to lie, deceive, break their promises, manipulate others, and even authorize murder and violence if they are to act well as politicians. ${ }^{7}$

I hold that dirty hands arise when an agent must choose between conflicting absolute moral claims because this ensures that whatever they do a particularly significant kind of moral remainder will obtain. Following Stuart Hampshire, I understand absolute moral claims as those not "conditional on, or subordinate to, any further moral claim or purpose." ${ }^{8}$ Calling a moral claim absolute in this sense signals that there are no circumstances in which it ceases to be morally relevant or altogether lacks normative force. This is not to be confused with the suggestion that absolute moral claims necessarily defeat all other claims, not least because a moral claim may be absolute in this sense and conflict with another absolute moral claim. When this occurs, regardless of how one chooses to act, one of the absolute moral claims is "in the final decision overridden, even though it has not lapsed."

${ }^{3}$ Michael Walzer, "Political Action: The Problem of Dirty Hands," in Thinking Politically: Essays in Political Theory (New Haven, CT: Yale University Press, 2007), 278-95.

${ }^{4}$ Dennis Thompson, Political Ethics and Public Office (Cambridge, MA: Harvard University Press, 1998), 13.

${ }^{5}$ Kai Neilsen, "There Is No Dilemma of Dirty Hands," in Politics and Morality, ed. Igor Primoratz (Basingstoke: Palgrave, 2007), 30.

${ }^{6}$ Steve de Wijze, "Dirty Hands: Doing Wrong to Do Right," in Primoratz, Politics and Morality, 12.

${ }^{7}$ See John Parrish, Paradoxes of Political Ethics: From Dirty Hands to the Invisible Hand (Cambridge: Cambridge University Press, 2007), 2; Bernard Williams, "Politics and Moral Character," in Moral Luck: Philosophical Papers 1973-1980 (Cambridge: Cambridge University Press, 1999), 58.

${ }^{8}$ Stuart Hampshire, "Public and Private Morality," in Morality and Conflict (Oxford: Blackwell, 1983), 115.

${ }^{9}$ Ibid., 116. 
The suggestion that the diverse moral claims that give substance to our ethical and political lives cannot either be reduced to or regulated by a supreme value (e.g., utility) or moral decision procedure (e.g., the categorical imperative) is thus fundamental to my understanding of the dirty hands thesis.

In this respect, I follow Stephen de Wijze in holding that dirty hands arise when two competing moral claims "cannot be satisfied and deciding to act one way rather than another does not eradicate all the force of the other." In such cases, although the overridden value "may not serve to guide one's action ... it still remains to exert an influence on how one feels, and importantly, on what one has become." ${ }^{10}$ However, this characterization needs to be supplemented given that the moral phenomenon described also transpires in numerous everyday situations where agents must choose between incommensurable values. Many of the momentous decisions we make about our lives require us to sacrifice some values/principles in order to have a chance of realizing other values/principles, but it stretches credulity to insist that these weighty choices inevitably implicate us in grievous moral wrongdoing of the sort at stake in the dirty hands thesis. We must distinguish the remainders associated with dirty-handed decision making from more commonplace remainders that are generated when agents choose between plural and conflicting values.

De Wijze acknowledges this, arguing that what sets dirty hands apart from ordinary moral conflict is that the agent is "immorally coerced to further an evil project" instigated by others, "because of moral values she may hold." ${ }^{11}$ I disagree. As I show in this article by discussing compromising in politics, dirty hands can arise absent the kind of "immoral coercion" de Wijze has in mind. In contrast to de Wijze, I hold that one dirties one's hands when one makes a good-faith choice between plural and conflicting values in a way that generates "residual moral claims" from other agents. Consider the examples that drive Michael Walzer's path-breaking analysis. In the first, a candidate must decide whether to make a shady deal with a corrupt ward boss in order to win an election. So long as this is a significant enough election, Walzer claims they should, despite their own misgivings and despite the fact that many of their supporters champion them because they believe they would not make such a deal. In the second, he claims that a political leader must authorize the use of torture in order to prevent a devastating terrorist attack harming their citizens. ${ }^{12}$ In both cases, the moral remainder the decision generates has a unique character. It does not simply signal that a good-faith attempt to choose between plural and competing values has occurred and that this decision has not nullified the normative

${ }^{10}$ De Wijze, “Dirty Hands," 8. For further discussion see Christina Nick, “Can Our Hands Stay Clean?," Ethical Theory and Moral Practice 22 (2019): 926; Michael Stocker, Plural and Conflicting Values (Oxford: Clarendon, 1990), 13.

${ }^{11}$ De Wijze, "Dirty Hands," 15-16.

${ }^{12}$ Walzer, "Political Action," 282-84. 
force of the moral claims that were, in the final instance, overridden. Beyond that, both examples also suggest that other agents-in the former case, the candidate's supporters, and in the second, the torture victim - have a residual moral claim against the politician because they have, in one way or another, been wronged by the politician's decision even if it can be justified all-thingsconsidered. Indeed, in both cases the public at large might have a legitimate moral complaint about the politician's behavior insofar as authorizing torture and engaging in political corruption arguably violate core standards which professional politicians are expected to uphold because they underpin the democratic politics itself.

This explains the force of Walzer's insistence that the dirty-handed politician is "guilty of a moral wrong" and that acknowledging this is the only way he can show us "both that he is not too good for politics and that he is good enough." ${ }^{13}$ Similarly, Bernard Williams holds that even if a politician has made the best decision all-things-considered, various people can still have a "justified grievance" about the way they have behaved. In such scenarios, Williams claims that it is wrong to "expect those particular people who have been cheated, used, or injured to approve of the agent's action, nor should they be subjected to the patronizing thought that, while their complaints are not justified in terms of the whole picture, they are too closely involved to be able to see that truth." ${ }^{14}$ According to Williams, we should refrain from admonishing these people for failing to see the world from some supposedly authoritative (because unprejudiced) "independent" point of view. Instead, we respect them by accepting they have, indeed, been wronged.

With this understanding of the problem of dirty hands in place, in the next section I consider the ethics of compromising.

\section{Making Sense of Compromise}

Compromise is a way of peacefully resolving a dispute or conflict. The need to compromise obtains when "two or more actors have conflicting individual or collective goals and/or principles, and where these actors stand to benefit from reaching an agreement or embarking on a course of action rather than from maintaining the status quo." ${ }^{15}$ For such an agreement to occur, all sides must make sacrifices which are determined by the will and tenacity of their opponents. Because compromising involves sacrifices of this sort, each party ends up getting less than they want, and often less than they think they are entitled to. ${ }^{16}$

${ }^{13}$ Ibid., 279.

${ }^{14}$ Bernard Williams, "Moral Luck," in Moral Luck, 37.

${ }^{15}$ Richard Bellamy, Markus Kornprobst, and Christine Reh, "Introduction: Meeting in the Middle," Government and Opposition 47, no. 3 (2012): 284.

${ }^{16}$ See Amy Gutmann and Dennis Thompson, The Spirit of Compromise: Why Governing Demands It and Campaigning Undermines It (Princeton: Princeton 
Thus, all compromises involve mutual concessions. Moreover, though compromising improves the status quo it is always suboptimal with regard to each parties understanding of their legitimate entitlements and/or preferred outcomes. ${ }^{17}$ That one who accepts a compromise still sees their initial position as superior to the compromise agreement explains the ambivalence we feel when assessing compromises from the moral point of view.

Theorists often include compromise in their lists of dirty handed political decisions. John Parrish remarks that in politics one must often "lie, betray, compromise, abandon, mislead, manipulate, coerce, or otherwise act in ways that, were one not to claim one's political responsibilities as an excuse, would seem thoroughly vicious and corrupt." ${ }^{18}$ Similarly, David Archard stresses that "the reality of quotidian politics is that politicians must frequently deceive, break promises, lie, cheat, bully, and compromise."19

These bold claims ought to be treated with caution. Anyone who has enjoyed a meaningful personal relationship will have engaged in compromise on numerous occasions in order to sustain that relationship without thinking they were involved in grievous wrongdoing. The way that compromise is often cast alongside deception, manipulation, coercion, and the sanctioning of violence in the dirty hands rogues' gallery should therefore be treated with caution; these latter acts are (at least) presumptively wrongful in nonpolitical contexts in a way that compromise simply does not appear to be.

Of course, one might insist that compromising in politics is inevitably dirty because nearly all political disputes involve conflicts of principle and the only morally upright way to respond to invitations to compromise on matters of principle is to refuse. Some hard-nosed interpretations of morality, which overwhelmingly think of moral claims in the language of moral obligation and paint these obligations as categorical requirements, often suggest that moral principles simply should not be subject to negotiation. According to proponents of such views, if one views one's principles as valid, and therefore considers oneself to be on the right side of a moral or political conflict, it is hard to see how the other party can have "a legitimate claim that must be

University Press, 2012), 10; Andrew Sabl, "Necessary Compromise and Public Harm," in Compromise, ed. Jack Knight, Nomos 59 (New York: New York University Press, 2018), 248.

${ }^{17}$ See Bellamy, Kornprobst, and Reh, "Introduction," 284; Daniel Weinstock, "Compromise, Pluralism, and Deliberation," Critical Review of International Social and Political Philosophy 20, no. 5 (2017): 628. This is why political compromises must be distinguished from cases of moral correction where adversaries change their minds and end up agreeing about the optimal thing to do: May, "Principled Compromise," 318-19; Rostboll, “Democratic Respect and Compromise," 622.

${ }^{18}$ Parrish, Paradoxes of Political Ethics, 2.

${ }^{19}$ David Archard, "Dirty Hands and the Complicity of the Democratic Public," Ethical Theory and Moral Practice 16, no. 4 (2013): 781. See also Neil Levy, "Punishing the Dirty," in Primoratz, Politics and Morality, 52n26. 
taken into account and satisfied to some degree." ${ }^{20}$ Compromise is consequently presented as a "temptation" or "corruption" which the moral politician must refuse on pain of becoming complicit in the perpetration of a morally regrettable state of affairs and degrading their moral integrity. ${ }^{21}$

I believe this view, often unspoken or assumed, underwrites the cursory attempts to link the making of political compromises with the dirtying of one's hands examined above. But there are two basic errors with attempting to impugn compromising on matters of principle in politics in this way. First, those who reason about compromise in this way are committing a category mistake. Anyone who engages in a political compromise knows that the settlement they reach will not fully express their principled commitments and/or view of their legitimate entitlements (or of their representees). But this does not reveal that they have displayed a lack of moral integrity and/or genuine normative commitment. To see why, consider G. A. Cohen's distinction between the "fundamental normative principles" which express our deep moral commitments and the "rules of regulation" that we adopt to realize those principles in our imperfect world. ${ }^{22}$ Drawing on this distinction, Eric Beerbohm suggests that "the site of the back and forth of compromise was what rules of regulation to adopt, given the background disagreement about . . . moral principles." ${ }^{23}$ Those who refuse to compromise on matters of principle, because they think this is a morally corrupt enterprise, thus overlook the distinction between the evaluative judgments one makes about the world and the practical decisions one makes about how to act in it. Once we recognize this, it is unclear why choosing to make political compromises on matters of principle necessarily means that one betrays their normative principles. Of course, some political compromises might legitimately be impugned for that reason, but it is fallacious to think that all can be.

Second, one might object to the uncompromising stance on normative grounds. In politics, it is sometimes necessary to compromise in order to mitigate public harm. For example, compromising on the debt ceiling might be necessary to avoid a government shutdown. ${ }^{24}$ Or one might need to make tactical concessions to facilitate a compromise that improves an unjust status

${ }^{20}$ Theodore Benditt, "Compromising Interests and Principles," in Compromise in Ethics, Law, and Politics, ed. J. Roland Pennock and John W. Chapman, Nomos 21 (New York: New York University Press, 1979), 31.

${ }^{21}$ For useful discussion (not necessarily endorsement) of this way of thinking about compromise see Eric Beerbohm, "The Problem of Clean Hands: Negotiated Compromise in Lawmaking," in Knight, Compromise, 20; Benditt, "Compromising Interests and Principles," 31; Martin Benjamin, Splitting the Difference: Compromise and Integrity in Politics (Lawrence: University Press of Kansas, 1990), 8; Sabl, "Necessary Compromise," 248.

${ }^{22}$ G. A. Cohen, Rescuing Justice and Equality (Cambridge, MA: Harvard University Press, 2008), 21.

${ }^{23}$ Beerbohm, "Problem of Clean Hands," 22.

${ }^{24}$ Sabl, "Necessary Compromise," 263-66. 
quo, as Nye Bevan arguably did by agreeing to maintain aspects of private healthcare in the construction of the British National Health Service (NHS) when he was minister of health in the aftermath of World War II. ${ }^{25}$

Such considerations generate normative reasons to compromise:

\begin{abstract}
P1. In a democracy, compromise is often necessary if one is to significantly improve the status quo or mitigate serious public harm. ${ }^{26}$

P2. If the status quo denies citizens' their rightful entitlements and could be ameliorated (if not fully rectified) by compromise, or the threat of impending public harm can be avoided by compromise, then politicians who refuse to compromise are in some way responsible for the suffering that results from their intransigence. ${ }^{27}$

C. Politicians have good reason to compromise when refusing to do so will either cause public harm or preserve a remediable, unjust status quo.
\end{abstract}

This illustrates why it is foolish and dangerous to see politics as a purity contest in the way that advocates of the uncompromising stance implicitly urge: foolish because this view rests on an impoverished philosophical understanding of the relationship between abstract principle and practical decisionmaking and dangerous because it is likely to implicate one in wrongdoing, perpetrate harm, and impede the amelioration of the status quo.

It would be a form of grave self-indulgence for a politician to refuse to compromise just because of the moral discomfort they feel about agreeing to a settlement that does not fully live up to their principles and values. This is not to say that, in such a situation, it would be irrational for them to feel regret (as we will see below). But when one poses the practical question of whether to compromise, politicians ought to be governed not by the desire to minimize their personal moral discomfort but by the need to deliver the best (or least bad) outcomes. If they attempt to preserve their moral purity by refusing to compromise they should be reproached for failing to accord with a political ethic of responsibility. ${ }^{28}$

\footnotetext{
${ }^{25}$ Mark Philp, “What Is to Be Done? Political Theory and Political Realism," European Journal of Political Theory 9, no. 4 (2010): 479.

${ }^{26}$ See Suzanne Dovi, The Good Representative (Oxford: Blackwell, 2007), 164; Gutmann and Thompson, The Spirit of Compromise, 101; Sabl, "Necessary Compromise," 260.

${ }^{27}$ See Benjamin, Splitting the Difference, 149; Gutmann and Thompson, The Spirit of Compromise, 108.

${ }^{28}$ Max Weber, "Politics as a Vocation," in Weber: Political Writings (Cambridge: Cambridge University Press 1994), 309-69. See also Susan Mendus, Politics and Morality (Cambridge: Polity, 2009); Thomas Nagel, "Ruthlessness in Public Life," in Public and Private Morality, ed. Stuart Hampshire (Cambridge: Cambridge University Press, 1978), 75-92. In this spirit, Nick, “Can Our Hands Stay Clean?," powerfully suggests that when confronted with a dirty hands situation, one's hands might emerge dirty however one chooses to behave.
} 
Lepora and Goodin develop a more sophisticated account of how we should reason about compromising, stressing that agents who compromise acquire responsibility for what they agree to do collectively as coprincipals to an agreement. They highlight two distinct forms of responsibility: committing responsibility (for what one agrees to undertake as part of a compromise) and omitting responsibility (for what one agrees to omit doing as part of a compromise). Given that, from the perspective of all parties, compromise settlements are suboptimal, various things one commits or omits to do will be regarded as pro tanto wrong by the coprincipals. However, that parties to a compromise regret aspects of the agreement does not limit their responsibility because even if one acts regretfully this does not mean one has acted involuntarily. $^{29}$

Lepora and Goodin maintain that compromising on matters of principle will often be experienced as morally discomforting and that this should be so. They maintain that regret is not only appropriate but the correct way of recognizing the "moral gravity" of the decisions one makes even if opting to compromise can be justified in terms of the moral bottom line. ${ }^{30}$ And despite accepting that the bottom line must be "morally veridical," they maintain that their framework promises "a way through the conundrum of the dirty hands debate" because it shows why one ought to act on the bottom line while also explaining why acting in this way generates serious moral costs which those responsible for the compromise should regret. ${ }^{31}$

In this section I have discussed the ethical quandaries that compromising throws up in general and noted the attractions of Lepora and Goodin's approach. However, in the next section, I argue that their framework needs to be supplemented in various ways if it is to help us to make sense of the ethical complexity inherent in compromising in democratic politics.

\section{The "Bads" Political Compromises Spawn}

Despite the virtues of Lepora and Goodin's general framework for thinking about the ethically fraught nature of compromising on matters of principle, it struggles to explain why political compromises ineluctably seem to generate dirty hands. First, their framework presents choosing to compromise as much like any other morally difficult decision agents may make because all genuinely difficult moral decisions can be analyzed in terms of the goods and bads of commission or omission. Though there is a sense in which this is an attractive feature of their framework, it obscures some salient ways that political compromises differ morally from other regretful decisions

${ }^{29}$ Chiara Lepora and Robert Goodin, On Complicity and Compromise (Oxford: Oxford University Press, 2013), 23-26.

${ }^{30}$ Ibid., 28.

${ }^{31} \mathrm{Ibid}, 28 \mathrm{n} 23$. 
ordinary agents sometimes make. If we are to make sense of the relationship between political compromise and the problem of dirty hands we need to pay more attention to the distinctive "bads" political compromises spawn.

Consider two compromises that a committed egalitarian politician (Anna) may agree to. In the former, she and her politically conservative partner Ben must reach a decision about whether their children will attend the local, state school (Anna's choice) or an expensive private school (Ben's choice). They agree to a compromise where the children will attend the private school on condition that Ben agrees to give away a high proportion of his inheritance to a charity that funds educational initiatives for disadvantaged children. In the second, a conflict about public funding of the university sector has arisen in Anna's state and neither of the party leaderships can secure the votes to implement their favored view without establishing cross-party support. One of the main parties has a history of cutting public funding of universities while Anna's has persistently sought to increase it. Moreover, Anna's constituency contains a large university that also employs a host of her constituents whom she must represent alongside a sizable student population. For these reasons, Anna strongly desires to maintain current levels of funding. Yet after much deliberation, she supports a compromise which maintains funding for STEM subjects on condition that degrees in the humanities and social sciences are defunded. Though she detests the way the bailout distinguishes between different academic disciplines, she does so because she believes the compromise provides the university sector with the greatest degree of continued public funding among the realistic alternatives on offer.

Because Lepora and Goodin's framework addresses compromise simpliciter it pushes us to regard these cases as more or less identical. It suggests that, in both scenarios, Anna should feel similarly regretful about her role in bringing about prima facie wrongs despite doing the right thing on balance. However, if we are to make sense of the second case, we need to pay close attention to the kinds of "bads" Anna becomes responsible for. There is a distinctive wrong involved in the second example which a compelling account of the relationship between political compromise and dirty hands must capture. In the second scenario, Anna sacrifices something of great concern to her representees when compromising. To get to grips with the moral dimensions of political compromise, we thus need to foreground the fact that politicians act as representatives. If we do not, we will be unable to make sense of the reasonable political resentments that even responsible political decision-making can generate. ${ }^{32}$

\footnotetext{
${ }^{32}$ This point has been powerfully made by Anton Ford, who uses it to cast doubt on the suggestion that politicians should make concessions to the other side which may be counterproductive to the pursuit of justice even if they are not required by strategic considerations or the balance of power (Ford, "Third Parties to Compromise," in Knight, Compromise, 53-79). Like Ford, in this article I emphasize the resentments that representees may make about political compromises reached on their behalf.
} 
Second, we have seen that Lepora and Goodin suggest that when politicians decide to compromise they must be guided by the bottom line and accept responsibility for the goods and bads that compromising generates, regretting their role in the perpetration of bad even if this is necessary to bring about greater good. While this approach may seem congenial to the dirty hands thesis, many dirty hands theorists do not merely argue that politicians who authorize such decisions should feel regret. They also claim that some bads generated by dirty-handed decision making are so serious that politicians ought to recognize that by authorizing such actions they are "guilty of a moral wrong." ${ }^{33}$ Even if justified all-things-considered, such decisions generate what I refer to as residual moral claims.

Lepora and Goodin's framework cannot explain how or why such residual moral claims obtain. We have seen that political compromises are sometimes necessary to avoid public harm and improve the status quo from the perspective of the principles one seeks to advance. If one accepts this, and endorses Lepora and Goodin's framework, it is hard to see how third parties could have a comprehensible residual moral claim against the politician who makes the right choice, all-things-considered, when they agree to compromise.

That said, the account of the distinctive bads of political compromise articulated earlier suggests one way such claims might be articulated from within their framework. To wit, it is tempting to hold that if politicians compromise on issues of principled concern to their representees they grievously violate their trust by abusing the core of the representative-representee relationship they are in. This appears to be Garrett Cullity's view when he states that even if a compromise is "skilfully practised" it nonetheless "always leaves some group with a legitimate complaint about the betrayal of trust." 34 However, this position is hard to sustain. If compromising can be valuable because it promotes outcomes that a politician pursues on behalf of their representees, as I have argued, it is inapt to characterize all compromises on matters of principle as grievous violations of trust. A politician who makes strategic concessions in order to faithfully and robustly advocate for their representees should feel regret and experience moral discomfort, but blaming them for acting in this way is undue. They can plead that by acting as they did, in a situation where they could not simply get their own way, they did right by their representees insofar as the circumstances regretfully allowed. In such cases, it is not clear their representees have a legitimate complaint

But, to preview the argument to come, I also stress that co-compromisers can resent the ways that their adversaries negotiated a compromise in order to do right by their representees in the kind of way Ford, in effect, advocates.

${ }^{33}$ Walzer, "Political Action," 279.

${ }^{34}$ Garrett Cullity, "The Moral, the Personal and the Political," in Primoratz, Politics and Morality, 58. 
against them. The politician has simply reacted to a recalcitrant political world, as they must.

This is not to deny that some political compromises will violate the trust of supporters in a way that can appropriately generate blame and residual moral claims. Think of a case where all prospective parliamentary candidates of a party sign a well-publicized pledge stating that, if returned at an upcoming general election, they will vote against $P$ and the overwhelming majority of their voters regard this as a sincere declaration. However, after the election, the party becomes the junior members of coalition and many of the elected candidates vote for $\mathrm{P}$ as part of a compromise which they believe best promotes their manifesto commitments taken as a whole. If the compromise really does have this character, it might be regarded as a dirty-handed political compromise, one that generates residual moral claims from third parties and not merely regret on the part of the politicians, because this behavior is genuinely morally condemnable. This is because the members of the party who voted for P could simultaneously be charged with violating the trust of their supporters, because they override prior promissory commitments that were taken up by them in the relevant way, even though their decision could, perhaps, be vindicated all-things-considered. ${ }^{35}$

Similarly, if a politician agrees to a compromise which sanctions the violation of some people's basic rights for consequentialist reasons-for example, by agreeing to support new national-security legislation which permits the use of "enhanced interrogation techniques" while robustly protecting against more "traditional" forms of torture-we might think that they should still be blamed, even if we think the compromise was, on balance, worth making.

So it seems that some of the time, agreeing to political compromises that improve the status quo can generate residual moral claims of the relevant kind. However, in liberal democracies, political compromises that involve political parties violating cast-iron promises that are accepted at face value by voters or which systematically violate citizens' basic human rights are mercifully rare. Most political compromises are more pedestrian even when they concern issues of principle. Thus, if the above noted kinds of political compromise alone generate dirty hands, the bold claims theorists make about the ineliminable relationship between compromising in politics and dirtying one's hands seem overblown and sensationalistic - the vast majority of political compromises are simply not this dramatic or normatively stark.

This is a standing possibility. Maybe only a small subset of political compromises truly has the potential to dirty a politician's hands. However, I think we should resist this deflationary conclusion because, as I argue in

${ }^{35}$ For an account of the importance of "uptake" in such contexts, see Judith Thompson, The Realm of Rights (Cambridge, MA: Harvard University Press, 1990), 296-98. 
the next section, a politician is likely to become blameworthy in the act of compromising rather than simply by choosing to compromise.

\section{Why Political Compromises Are Often Dirty}

In this section, I argue that a politician who seeks to justify compromising on strategic grounds - that is, as a way of enabling them to act as a faithful and committed advocate for their representees in difficult political circumstances - who on Lepora and Goodin's account appears blameless, is in fact likely to become blameworthy in the act of negotiating a compromise. To see why, I explain how the ethical requirements of good compromisemaking conflict with the obligation political representatives have to robustly advocate for their representees.

Though the literature does not answer the question of what the ethical requirements of compromise making are in a single voice, there are family resemblances between leading accounts which suggest three key features. First, that compromising, in contrast to other forms of negotiation such as bargaining, requires each party to willingly accommodate the other side even if this means that the resulting settlement does not secure the best possible outcome for themselves. Thus, Theodore Benditt declares that in a true compromise "a person has a certain sort of respect for his opponent, because of which he is willing to agree to an accommodation rather than make the best deal ... he can." ${ }^{36}$ Similarly, Richard Bellamy maintains that when negotiating a good compromise, one must refrain from seeking "to get as much of their own way as they can" and instead "try to accommodate others as far as possible." ${ }^{37}$

Second, though compromise requires mutual concessions, one should refrain from pushing the other side into making "disproportionate concessions" which fall "below a threshold of acceptability with respect to their core values." ${ }^{38}$ Such settlements must be avoided because they fail to show the other side respect.

The third major element of ethics in compromise concerns the need for parties to negotiate in a broadly honest and transparent way. In political contexts, this means that adversaries must "maximize reasonable transparency" 39 and practice "rich information-sharing and openness." ${ }^{40}$ This demand can be contravened in various ways. One may present a series of sham commitments which are espoused so they can later be dropped "so as to increase one's share" instead of truthfully proclaiming one's credible

\footnotetext{
${ }^{36}$ Benditt, “Compromising Interests and Principles," 26-27.

${ }^{37}$ Bellamy, Liberalism and Pluralism, 111.

${ }^{38}$ Weinstock, "Compromise, Pluralism, and Deliberation," 652.

${ }^{39}$ Michele Moody-Adams, "Democratic Conflict and the Political Morality of Compromise," in Knight, Compromise, 190.

${ }^{40}$ Bellamy, Kornprobst, and Reh, "Introduction," 288.
} 
commitments. ${ }^{41}$ Or one may exaggerate just how unacceptable a certain proposal is, or how costly a floated concession would be, by threatening to walk away unless the other party commits to the concessions one desires. ${ }^{42}$ To the extent that such behavior is deceptive it is objectionable; deception has the potential to invalidate the binding nature of the compromise by undermining the "authenticity of the consent given by one of more of the parties." 43 Indeed, Martin Benjamin proposes that seeking to a secure a "competitive edge" by exploiting one's power, or engaging in various kinds of deception, corrupts the practice of compromising by eviscerating its moral preconditions. ${ }^{44}$

Though there is a great deal to be said in favor of this vision of ethics in compromise, it is no great stretch to suppose that these principles condemn almost all of the hard-won political compromises we revere. This should lead us to ask if admirable politicians would, in fact, accord with these moral requirements when negotiating a political compromise. Consider the UK's attempt to extricate itself from, and determine its future relationship with, the EU. It is implausible to claim that, in this politically fraught negotiation, David Davis or Michel Barnier would have acted in a politically responsible manner by being completely transparent about the concessions they were prepared to make, and those they considered beyond the pale, at the onset of the negotiations. Nor would they have acted in a politically responsible way had they unilaterally attempted to accommodate the other side without any guarantee they would be accommodated in turn. That much real politics is characterized by the kind of mutual mistrust and anxiety that beset the Brexit negotiations may be lamentable, even if it is in some sense inevitable. But the important point is that had Davis or Barnier unilaterally accorded with the requirements of ethics in compromise they would have left themselves open to manipulation and disadvantaged their representees. In other words, they would have acted in a politically negligent way.

It thus appears that the adversarial contexts in which political compromises are forged limit the extent to which we can expect good politicians to abide by the requirements of ethical compromise making. This supports a core element of the dirty hands literature: the claim that the competitive contexts in which they must act drastically "limit the range of effective actions available to the serious politician." 45 A reckoning with political reality problematizes the claim that a good politician should always conform to the requirements of ethical compromise-making. The problem is not that doing so is often

\footnotetext{
${ }^{41}$ Margalit, On Compromise and Rotten Compromises, 47. See also Beerbohm, "Problem of Clean Hands," 8-9; Benditt, "Compromising Interests and Principles," 36.

${ }^{42}$ Beerbohm, "Problem of Clean Hands," 9.

${ }^{43}$ Peter Jones and Ian O'Flynn, "Can a Compromise Be Fair," Politics, Philosophy, and Economics 12, no. 2 (2013): 125.

${ }^{44}$ Benjamin, Splitting the Difference, 137-38.

${ }^{45}$ Parrish, Paradoxes of Political Ethics, 13.
} 
politically inconvenient; it is that doing so is likely to mean that a politician will fail to do right by their representees.

So what it takes to be an effective and responsible representative must play a fundamental role in our judgments about whether a politician acts well when negotiating a compromise. Though the literature on political representation is legion and increasingly technical, I take it as uncontroversial that, in a democracy, representatives must act as faithful and committed advocates for their representees. ${ }^{46}$ Though people have competing views of the proper requirements of this role, the idea that democratic representatives should act as faithful and committed advocates for their representees is ecumenical enough to be compatible with a plethora of reasonable views-including delegate and trustee conceptions. On the former, one would hold that a good representative must pursue the ends that their principals have entrusted them to pursue. On the latter, one would hold that a good representative must robustly pursue the ends that they believe will best secure their representees' interests. Compromising can be a practically effective way for both delegates and trustees to faithfully advocate for their representees for reasons already discussed.

Many advocates of the dirty hands thesis, drawing on the realist tradition in political thought, insist that political efficacy is a central element of plausible views of admirable political conduct. For example, Galston remarks that good politicians recognize "the responsibility to act effectively, which not infrequently entails the obligation to use the kinds of tactics a decent person will regard as intrinsically disagreeable." ${ }^{\prime 7}$ This suggests that admirable politicians need to cultivate a particular disposition Galston calls "toughness" lying between the vices of squeamishness and callousness. ${ }^{48}$ It follows that when they compromise, they need to act "toughly" acting in a strategic and tenacious way for their representees.

It does not follow that one is a good democratic representative if they robustly advance whatever their representees happen to desire. There are grounds for thinking that admirable representatives will not set out to undermine basic democratic norms and values. ${ }^{49}$ But so long as we do not operate with an implausibly expansive view of the basic norms and values that underpin democratic politics (and their concrete implications) we ought to

${ }^{46}$ Following Michael Hardimon, I understand a role obligation as a "moral requirement, which attaches to an institutional role, whose content is fixed by the function of the role, and whose normative force flows from the role" ("Role Obligations," Journal of Philosophy 91, no. 7 [1994]: 333-63). Hardimon insists that for such obligations to obtain the role must be "reflectively acceptable" (348). I assume the role of democratic representative satisfies this test.

${ }^{47}$ William Galston, "Value Pluralism and Political Means: Toughness as a Political Virtue," in The Practice of Liberal Pluralism (Cambridge: Cambridge University Press, 2005), 83.

${ }^{48}$ Ibid., 75-94.

${ }^{49}$ Dovi, The Good Representative, 100-123. 
acknowledge that many of the positions that mainstream parties in contemporary liberal democracies support are likely to fall within this range. In addition, some ethical constraints surely determine the boundaries of admirable political tenacity. After all, it is hard to give much credence to the view that it would have been appropriate for Davis to threaten to blackmail Barnier if he did not agree to endorse the May government's proposals. Yet even if one accepts that some (thin) moral constraints determine the boundaries of reasonable political tenacity it stretches credulity to suppose that these constraints just are the (thick) constraints articulated by the accounts of ethics in compromise. We have seen that politicians who choose to accord with these constraints when they have no guarantee their adversaries will reciprocate open their representees to mistreatment. If one accepts that efficacy is a political virtue, as nearly all commentators $\mathrm{do}^{50}{ }^{5}$ one should acknowledge it is unreasonable to demand that politicians comply with a set of ethical guidelines that are extremely likely to render them ineffective in the pursuit of the ends they been entrusted to pursue.

Though this account of "tough negotiation" is undeniably sketchy and incomplete, it has important implications. Recognizing that politicians compromise on behalf of third parties dramatically limits the appeal of views which claim that politicians must "offer unforced concessions that are not necessitated by balances of power or by any strategic consideration about how to advance justice, and that are, in one's view, counterproductive to that end." ${ }^{11}$ It also supports the view that so long as gross public harm is unlikely to result from refusing to compromise, sometimes "being a tough negotiator-even at the risk of inaction-may be politically and ethically admirable, as may enacting a party program that commands majority support while being bitterly opposed by the other side." 52

The argument of this section thus suggests that however a politician chooses to negotiate a weighty compromise, residual moral claims of the relevant kind are likely to arise. To the extent that representatives take their role responsibility to be faithful and committed advocates seriously they have reason not to accord with the requirements of ethics in compromise. At the same time, to the extent that representatives take the requirements of ethics in compromise seriously, they have reason not to negotiate toughly. Reasonable grievances about the way that a political compromise was negotiated can, therefore, be made from either direction even if the decision to compromise can be vindicated all-things-considered from the perspective of both parties. If a politician accords with the requirements of ethics in compromise, their representees might reasonably complain that this has come at the cost of them being a good advocate. On the other hand, if a politician prioritizes being an effective advocate, they can be charged with violating the

\footnotetext{
${ }^{50}$ Ibid., $101-4$.

${ }^{51}$ Ford, "Third Parties to a Compromise," 55.

${ }^{52} \mathrm{Sabl}$, "Necessary Compromise," 278n31.
} 
requirements of ethics in compromise. It is in this sense that I believe that however a politician chooses to negotiate a political compromise someone will be wronged. Whatever they do, their hands will be dirty.

\section{Objections and Replies}

In this section I address a number of counterarguments to my view. First, one might object that politicians are only obliged to refrain from negotiating in the kind of "tough" ways I have described if they have principled reasons to pursue fair compromises with their adversaries, but that they will do no wrong by negotiating toughly if no such reasons exist, as some have argued. ${ }^{53}$

However, the argument advanced in this paper is in fact compatible with a plethora of the views that have been articulated in the debate about whether politicians have moral reasons to pursue compromises on matters of principle. Even if one only has instrumental or pragmatic reasons to $X$, it does not follow that one can ignore the normative requirements associated with Xing if doing so is instrumentally advantageous. Imagine I agree to review a book manuscript for the perfectly legitimate reason that I desire the financial reward offered by the publisher rather than the more edifying reason that I believe I have an obligation to serve my professional colleagues. It would not follow that it is acceptable to only read the first half the manuscript and skim the rest because that would be the most efficient way of writing a professional-looking report that would enable me to achieve my permissible end of getting paid. Similarly, even if a politician chooses to compromise for the kinds of "pragmatic" reasons May invokes, it does not follow that this cancels the normative requirements associated with compromising. What the normative requirements of Xing are is a different question from the reasons for Xing in the first place.

That said, it is plausible that politicians do no wrong if they violate the requirements of ethics in compromise when the other side seek to realize manifestly wicked ends. One might hold that all agents are obliged to do what they can to mitigate such terrible outcomes and that, therefore, in such cases the requirements of ethics in compromise are simply cancelled. In other words, compromising with such parties would be "rotten" not "dirty." However, this does not undermine my central argument. As argued earlier, it stretches credulity to claim that many of the positions mainstream parties in contemporary liberal democracies support can be regarded in these terms, even if we consider some of their policies/proposals unjust or morally problematic.

Of course, if one holds that one has overriding moral reasons to not- $X$ then it is hard to justify the need to accord with the normative requirements of Xing because one should not be Xing in the first place. But section 2 illustrates

${ }^{53}$ May, "Principled Compromise and the Abortion Controversy." 
that cannot be the case when one ponders many political compromises. My argument in that section does not hinge on the kind of second-order values-respect, inclusion, reciprocity-May addresses.

Second, one might object to my view by questioning the kind of moral requirement the authors who contribute to the literature on ethics in compromise have in mind: Are they merely describing various features of "good" political compromises or outlining the morally obligatory requirements cocompromisers are subject to in every compromise negotiation? Many of the contributions to that literature do not explicitly say. But the worry is that for the charge of dirty hands to stick, the ethical principles of good compromise making have to be regarded as "deontic musts" rather than aspirational moral claims. If they are regarded in the latter sense, when an agent violates them this would merely seem to generate the kind of regret that is associated with not doing something morally optimal, which I have argued is insufficient to ground the charge of dirty hands, rather than behavior which generates residual moral claims of the sort which I have claimed is central to the dirty hands thesis. ${ }^{54}$

Setting aside the fact that both kinds of moral requirement seem to be present (sometimes intertwined in complex ways) in many of the contributions to this literature, I believe it makes sense to regard many of the claims made about the preconditions of consent as "deontic musts" which all negotiators must comply with. This is necessary if the resulting agreement can be regarded as having been voluntarily agreed to, which many authors insist is crucial if the agreement is to be regarded as morally binding. Conversely, one might regard the claims authors make about co-compromisers accommodating the other side and/or refraining from pushing their adversaries to make disproportionate concessions as merely describing features of morally attractive political compromises. These latter claims do not seem to be obligatory in the same way.

However, residual moral claims of the relevant kind can emerge regardless of how we interpret the requirements of ethical compromise-making. If one sees these requirements as "deontic musts" it is uncontroversial that a negotiating party has a residual moral claim if they are subjected to tough negotiation tactics. Importantly, this is so even if such nefarious behavior is expected. That one expects another party to act deceitfully, and therefore is not in fact deceived when they do, does not necessarily mean that one has not been wronged.$^{55}$ Similarly, even if one expects their co-compromiser to disregard these deontic musts, and thus negotiates suspiciously, it does not follow they are not wronged. For such behavior to be rightful, one would have to hold that the obligation that representatives have to robustly advocate for their representees suspends the countervailing moral demand that

\footnotetext{
${ }^{54}$ Thanks to an anonymous reviewer for pushing me on this point.

${ }^{55}$ Seana Shiffrin, Speech Matters: On Lying, Morality, and the Law (Princeton: Princeton University Press, 2014), 17.
} 
compromise agreements be voluntarily consented to. But if one endorses the kind of value pluralism that motivates the dirty hands discussion, it makes more sense to see both demands as "absolute" in the sense described earlier, where this means neither lapses even if one is overridden by the other in particular circumstances.

From the opposite direction, if one frames the principles of ethics in compromise as ways of achieving "good" or "morally attractive" compromises, there are still grounds for thinking that third parties have legitimate residual moral claims against agents who negotiate toughly. To see why, instead of taking as given that the salient perspective is that of the other party in negotiation, we need to expand our perspective of who can be wronged by such behavior, and on what grounds, by asking how all those who have a stake and interest in the long-term health of democratic dispute resolution should regard such behavior. Once we take up this point of view, a way of making sense of the moral costs of tough political negotiation comes into view.

P1. Because compromising is a reliable way of peacefully improving the status quo and avoiding public harm, we should condemn behaviors that foreseeably undermine the practice of political compromise.

P2. The readiness to seek out mutually beneficial compromises in the future is likely to turn on whether one feels resentful about the ways they have been treated by adversaries in past negotiations. ${ }^{56}$

P3. Overriding the requirements of ethical compromise-making is likely to generate such resentments.

C. Therefore, by overriding the requirements of ethical compromisemaking one can be condemned for foreseeably playing a role in undermining a valuable political practice.

How can P2 and P3 be vindicated? As many of the advocates of ethics in compromise suggest, negotiating in these ways is a way of respecting one's cocompromisers and supporting the value of reciprocity. If one side feels like they have not been afforded such respect, they are likely to resent it and these resentments will color their attitude toward future compromise opportunities. To see this point, let us return to our earlier subject of discussion, Brexit. Because tough negotiation (understandably) shaped the negotiations concerning the withdrawal agreement, at the time of writing we are (predictably) in a situation where neither side is making a good faith attempt to resolve outstanding issues, like the Northern Ireland protocol, in a way that is likely to secure mutually beneficial, long-term cooperation between the UK and EU. The previous (tough) negotiations have ensured that good faith is in short supply and distrust and ill-feeling abound. Because of this, the UK and EU are becoming increasingly intransigent. Countless people, not just the inhabitants of Northern Ireland, are right to be resentful about

\footnotetext{
${ }^{56}$ See Beerbohm, "Problem of Clean Hands," 12-13.
} 
this. It not only has a very real chance of diminishing many people's economic prospects; it might even undermine the Northern Ireland peace process.

This suggests that even if some of the requirements of ethical compromisemaking should not be regarded as "deontic musts," tough negotiation is likely to generate residual moral claims because compromises are reliably effective ways of improving the political status quo and tough negotiation is likely to undermine the practice of seeking out mutually beneficial compromises in the long run.

None of this implies that elected representatives have dominant reasons to refrain from being tough negotiators in every negotiation; it just illustrates why negotiating important political compromises is so morally fraught. Most citizens recognize that functioning democracies are built on mutually satisfactory compromises while disliking particular compromises that threaten their principles and preferred outcomes. ${ }^{57}$ Similarly, though we have reason to value behavior that sustains mutually beneficial compromise-making, it does not follow that we must want our representatives to refrain from negotiating toughly tout court.

Third, one might object to my argument by claiming that if the ethical principles of good compromise-making obtain, then citizens cannot reasonably complain if their representatives refrain from negotiating "toughly." After all, we do not think that to act responsibly other kinds of representatives have reason to advocate for their representees in ways that violate ethical principles that constrain the robustness of their advocacy. For example, it is implausible to claim that to be a good legal advocate, a lawyer must be prepared to violate the prohibition against falsifying evidence to strengthen their client's case. This is why clients cannot reasonably complain if their lawyer refrains from falsifying evidence. Similarly, one might claim that political representatives must abide by moral constraints of ethical compromise-making even if this limits the effectiveness of their advocacy, with the result that their representees cannot reasonably complain if they refrain from negotiating "toughly."

However, this analogical argument is misleading. If a party to a legal dispute falsifies evidence, the other side can appeal to an established third party who has the authority to sanction such behavior. That a third party who is tasked with enforcing compliance with the relevant standards exists is fundamental to our judgments about the nature of responsible legal advocacy. It ensures that lawyers have reason to believe that according with the relevant constraints will not unfairly harm their clients because they can be reasonably confident their opponents will do the same. This simply is not the case when we think about political compromise. There is no analogous, independent third party who possesses the power and/or authority to adjudicate such disputes and to sanction political representatives who fail to abide by the principles of ethical compromise-making. This lack of an enforcement

${ }^{57}$ Gutmann and Thompson, Spirit of Compromise, 26. 
mechanism explains why political representatives cannot be confident that the other side will accord with the requirements of ethical compromisemaking.

Fourth, rather than thinking about the morality of political compromise in terms of dirty hands, one might insist that a single set of moral constraints determines what steps can legitimately be taken on behalf of any political constituency and that these constraints limit what a political representative of any such constituency is morally permitted to do in advancing the interests of the constituency. On this view, one is an admirable representative to the extent that one advocates tenaciously within these constraints. ${ }^{58}$

Though this is a coherent way to think about the ethics of political compromise, it has two unwelcome implications. First, this approach presumes that a supreme moral principle or more fundamental moral decision-procedure can arbitrate between the demands of ethics in compromise and robust representation in order to determine what the relevant underlying "single set of moral constraints" consists of. But this requires a positive argument, which has not been forthcoming. And, as I have shown, advocates of the dirty hands thesis are skeptical that moral theories which attempt to explain away moral conflicts in this way will succeed, primarily because they will fail to do justice to our lived moral experience.

Second, holding that there is a genuine conflict of duties at play, as the dirty hands view I am defending does, captures the widespread sense that, in a democracy, compromise agreements are morally fraught precisely because we feel that representatives both ought to robustly advocate for their representees and also pursue compromises that further the values associated with the theories of ethics in compromise which all citizens may benefit from. My view captures the sense that robust representation matters, but that it is not the only moral claim that matters when politicians forge compromises with their adversaries, far better than the alternative approach to the morality of political compromise under consideration here can.

Additionally, one might argue that no residual moral claims can obtain if politicians compromise ethically because all citizens have reason to appreciate the democratic value of well-crafted political compromises forged in accordance with the requirements of ethics-in-compromise. Beerbohm's approach to thinking about the ethics of political compromise arguably suggests such a view. ${ }^{59}$ He maintains that the democratic value of "deciding together" or "co-owning" legislation explains how compromise can make political decision-making "morally better" than it would otherwise be. ${ }^{60}$ To make this point, Beerbohm utilizes the idea that citizens stand in a

\footnotetext{
${ }^{58}$ Thanks to an anonymous reviewer for pushing me to respond to this counterargument.

${ }^{59}$ Beerbohm, "Problem of Clean Hands." Rostboll's "Democratic Respect and Compromise" essentially defends a similar view.

${ }^{60}$ Beerbohm, "Problem of Clean Hands," 6, 30.
} 
principal-agent relationship with their representatives and takes this to show that if political representatives compromise in a "nonstrategic" way-i.e., by refraining from toughly pursuing a set of sectarian ends, instead choosing to offer unforced concessions to the other side-they should be regarded as offering these concessions to other citizens. ${ }^{61} \mathrm{He}$ thus claims that the act of compromising secures a certain kind of valuable democratic relationship. This implies that citizens cannot reasonably complain if their representatives opt to accord with the requirements of ethics in compromise and refrain from acting as tenacious advocates for their partisan claims. It follows that refusing to accord with the requirements of ethics in compromise is objectionable from every relevant point of view. "Tough" negotiation would not be morally wrong but politically admirable - it would just be wrong, plain and simple.

Beerbohm may deny that this extrapolation fairly extends the logic of his argument. He refers to compromise negotiations as "partially suspended contexts" and claims we need to "find a place for strategic speech" in these settings. ${ }^{62}$ But I struggle to see how compromises reached following the use of the kind of strategic speech and behavior he has in mind are compatible with the "co-ownership" view he champions. Using such tactics undermines the idea that the resulting compromise is co-owned in the normatively appealing sense of the term that Beerbohm's argument depends on.

In any case, the general claim that no residual moral claims can obtain if politicians compromise ethically because all citizens have reason to appreciate the democratic value of political compromises forged in accordance with the requirements of ethics-in-compromise is unconvincing. Though the claim that we co-own the decisions our representatives make on our behalf seems to follow from the understanding of the principal-agent relationship theorists like Beerbohm employ, the idea of co-ownership only possesses the suggested edifying democratic implications in certain idealized conditions. For such an argument to succeed, citizens would have to regard their representative's conduct when negotiating as largely within their control. If they do not enjoy this kind of control, citizens merely coown their elected representatives' decisions in much the same way that Hobbesian subjects co-own the actions of their almighty sovereign - in a purely formal sense that lacks any democratically appealing features. Something is done on their behalf, but without any meaningful input from them.

It is a staple of contemporary political science that citizens do not enjoy much control of this sort. ${ }^{63}$ As John Dunn has long argued, though our rulers are in some sense accountable to us, it is an illusion to think that we possess the ability to meaningfully determine their decisions or

${ }^{61}$ Ibid., 33.

${ }^{62}$ Ibid., 18

${ }^{63}$ Christopher Achen and Larry Bartels, Democracy for Realists: Why Election Do Not Produce Responsive Government (Princeton: Princeton University Press, 2016). 
actions ${ }^{64}$ It is thus hard to see how negotiated political compromises in political societies like our own have the edifying democratic implications Beerbohm invokes.

These skeptical reminders call into question the idea that citizens of modern democracies enjoy the kind of political autonomy celebrated in various strains of contemporary democratic theory. But given that a clear-eyed understanding of contemporary political life supports these skeptical reminders, this is a problem for those views rather than the argument defended in this article. My view is less vulnerable to these features of modern democratic politics. I have not claimed that citizens "co-own" legislation in the wholesomely democratic way that Beerbohm's account trades on. I have merely argued that, in a democracy, politicians must act as faithful and committed advocates for their representees.

Finally, it might be thought that if one adopts a Burkean view of a representative's duty the problem I have highlighted becomes much less irremediable than I have painted it as being. On such a view, as members of a national parliament, elected political representatives must make judgments about what is in the interest of the public at large rather than their own constituents. With this in mind, one might be tempted to conclude that when Burkean representatives forge political compromises they do not have good reason to negotiate toughly because they are not merely delegates of their constituents but engaged in a different kind of political activity. The conflict I have highlighted between tough advocacy and ethics in compromise might be thought to fall away, at least to some extent. ${ }^{65}$

But a Burkean perspective on representation only undoes the conflict I have highlighted if one holds, first, that by negotiating "softly" Burkean representatives will converge on the national interest, and second, that all representatives will recognize this and change their negotiating tactics accordingly. These are clearly very controversial suggestions. If one disputes that democratic politics is ever likely to function in this highly idealized way for a prolonged period of time, as I believe we should, the conflict I have in mind will obtain in some form or other. Indeed, absent some fantastical convergence story, Burkean representatives who believe they are obliged to represent the public at large, rather than their own constituents, but who come to distinct judgments about what that requires or involves, will feel the need to negotiate "toughly" in order to act as faithful and committed advocates for the public whom they represent.

${ }^{64}$ John Dunn, "Democratic Theory," in Western Political Theory in the Face of the Future (Cambridge: Cambridge University Press, 1993), 1-28.

${ }^{65} \mathrm{My}$ thanks to an anonymous reviewer for pushing me to examine this objection. 


\section{Conclusion}

In this article I have argued that although we have reason to value the actions of politicians who forge harm-mitigating and status-quo-improving compromises, they are likely to dirty their hands when compromising because they will not be able to resolve without remainder the conflict between the requirements of ethical compromise-making and the obligation they have to act as faithful and committed advocates for their representees. It is in this sense that forging political compromises can be politically admirable while simultaneously involving uncanceled moral wrongdoing.

Though I have not addressed the issue of how politicians might compromise well, my argument implies that the best we can hope for is a form of responsible compromise-making that attempts to do some justice to the distinct values that underpin the principled arguments that can be made in favor of ethical compromise-making and robust representation. A cleareyed analysis of this core issue in political ethics thus reaffirms Max Weber's fundamental lesson about the vocation of politics. Weber stresses that responsible politicians must "truly feel what they are taking upon themselves" and maintain an unflinching focus on the foreseeable consequences of their actions. ${ }^{66}$ When forging compromises that improve the political status quo responsible politicians must do exactly that. The truthful among them will also acknowledge that even if the decision to compromise can be vindicated on balance, the process of compromising will generate dirt that lingers nevertheless because the moral costs of political compromises do not come out in the wash. They will also recognize that determining how the resulting resentments and disappointments should be managed, and how they can be contained, is incredibly important for the long-term health of their polities. But this is, ultimately, a question of political judgment about which, I suspect, there is little that political theorists can say at the philosophical level.

${ }^{66}$ Weber, "Politics as a Vocation," 367. 